\title{
DIFUSI INOVASI MANAJEMEN PERUBAHAN MODEL KURT LEWIN PADA MADRASAH DENGAN PENDEKATAN PRINSIP TRINGA
}

\author{
NUR SA'IDU \\ Pengawas Madrasah Kementerian Agama Kabupaten Semarang \\ e-mail: nuripurbosari68@gmail.com
}

\begin{abstract}
ABSTRAK
Pandemi Covid-19 sangat berdampak besar dalam dunia pendidikan, salah satu efek yang sangat terkena adalah sistem pembelajaran dalam keberlangsungan mutu pendidikan. Tingkat resiliensi pendidikan menumbuhkan sikap optimisme dengan manajemen perubahan. Salah satu model manajemen perubahan yang adaftif dengan kondisi pendidikan di masa Pandemi Covid -19 adalah pendekatan manajemen perubahan Model Kurt Lewin (Unfreeze, Change, Refreeze) dengan pendekatan humanis Prinsip " Tringa" (Ngarti, Ngrasa, Nglakoni) Kihajar Dewantara. .Berbagai regulasi pemerintah dalam pencegahan coronavirus disease Covid-19 telah ditebitkan sebagai panduan pnyelenggraan pembelajaran di masa pandemi covid19, yang memunculkan pendekatan baru dalam pembelajaran dengan PJJ (daring, luring, blended) dengan mengdaptasikan berbagai aplikasi LMS (Learning Manajemen System) baik dengan syncronous asyncronous, memaksa pelaku pendidikan untuk meningkatkan kompetensi penguasaan teknologi digital. Untuk menjaga mutu pendidikan perlu adanya kontrol terhadap penjaminan mutu melalui supervisi pendidikan Pengawas dalam melaksanakan supervisi akademik dan manajerial dalam pembinaan, pemantauan dan evaluasi tehadap Kepala Madrasah, Guru dan Tenaga Kependidikan. Kepala madrasah mempunyai posisi sangat penting dalam pengelolaan majemen perubahan dengan melakukan supervisi akademik sebagai upaya pembinaan dalam meningkatkan kinerja guru dalam proses pembelajaran dan menciptakan proses pembelajaran yang efektif. Sedangkan pendekatan supervisi klinis digunakan kepala madrasah untuk mengembangkan kemampuan guru agar bertanggung jawab terhadap kinerja guru dan terbuka adanya manajemen perubahan. Madrasah sebagai institusi pendidikan hendaknya dapat mengadopsi manajemen perubahan pendidikan untuk menata ulang strategi pendekatan pelaksanaan pendidikan pada tahapan normalisasi Madrasah teruitama pada tatanan pendidikan menuju kenormalan baru dengan berbagai pembenanahan kurkulum yang ada dan memodifikasi internalisasi promosi pendidikan kesehatan dapat diterapkan pada madrasah sebagai antisipasi perubahan pendidikan dalam kerentanan resiko kesehatan global dimasa mendatang.
\end{abstract}

Kata Kunci : Difusi Inovasi, Manajemen Perubahan, Model Kurt Lewin, Tringa

\section{PENDAHULUAN}

Pandemi Covid-19 berdampak besar bagi dunia pendidikan. Upaya pemerintah menekan penyebaran dilakukan dengan sangat ketat dengan beberapa regulasi yang ada. Namun selain regulasi pemerintah juga harus mampu membangun resiliensi pendidikanyang kuat untuk menumbuhkan resileinsi yang baik di masyarakat dalam membantu tetap terselengaranya pendidikan Salah satu efek posistip adalah cara pandang melihat pandemi Covid-19 dari sisi positifnya dapat dijadikan sebagai faktor yang dapat meningkatkan resiliensi pendidikan dimana adanya Covid-19 menjadi mesin pendobrak kemajuan guru dalam inovasi pendidikan dengan optimisme menuntut bergerak maju kearah peningkatan kualiatas mutu pendidikan, pembelajaran serta profesinalitas guru.

Dalam resiliensi Pendidikan pandangan optimis terhadap pandemi Covid-19 bisa dijadikan ukuran tentang kualitas pendidikan, kualitas penguasaan kemam- puan IT guru, kualiatas sistem pembelajaran yang tidak dibatasi oleh ruang kelas (fisik) saja. Pandemi mendororng percepatan pembangunan dengan menggunakan platform pendidikan nasional berbasis teknologi. Pandemi covid-19 memaksa semua stake holder pendidikan untuk berfikir 
ulang tentang pendekatan sistem pembelajaran yang tepat menuju tercapaianya tujuan pendidikan.

Sejalan dengan hal tersebut sebagaimana pernyataan Muhammad Ramli Rahim, ketua umum Ikatan Guru Indonesia (2000) menyatakan " Pandemi covid-19 menjadi era kebangkitan guru milenial di Tanah Air. Pada prinsipnya teknologi tidak akan pernah menggantikan guru, tetapi guru yang tidak paham teknologi suatu saat akan digantikan oleh guru-guru yang faham dan menguasai teknologi". Dengan demikian adanya pandemi Covid-19 memaksa guru harus mampu mengerti, memahami, melaksanakan tugas mengajar dengan teknologi dengan berbagai platform komunikas media pembelajaran.

Disisi lain Madrasah sebagai organisasi institusi pendidikan memegang peran penting dalam dalam menginternalisasi nilai-nilai kesehatan pada anak. Sekolah melalui aktivitas guru menjadi katalisator antara siswa dan isu-isu penting tentang kesehatan yang akan memberikan dampak pada komunitas siswa berada (Webb, 1985). Hal ini tidak terlepas dari normalisasi madrasah dalam internalisasi kesehatan belajar dari pengalama masa Pandemi Covid-19. Kondisi kedaruratan yang kesehatan seperti yang terjadi saat akan menjadi resiko kerentanan kesehatan global di masa depan (Bello, 2020), sehingga perlu disikapi melalui kemampuan adaftif dalam mengantisipasi ancaman wabah di masa mendatang. Dengan pemaparan tersebut maka pelaksanaan pendidikan pada masa pandemi hendaknya dipahami secara menyeluruh bagi dunia pendidikan serta warga masyarakat terutama dalam sistem perubahan pembelajaran yang menimbulkan resiliensi pendidikan menuntut keterlibatan masyarakat sebagai masyarakat pembelajar.

Untuk mengatasi akibat perubahan-perubahan tersebut, salah satu model manajemen perubahan yang mampu beradaptasi dengan perubahan-perubahan salah satunya adalah manajemen menurut Kurt Lewin. Menurut Kurt Lewin (dalam Hussain.et.al, 2016) mengatakan bahawa teori model Lewin merupakan teori fundamental awal yang terencana yang menjelaskan kekuatan dari perjuangan untuk mempertahankan status quo dan mendorong untuk perubahan.Teori ini merupakan teori sederhana dan memiliki kerangka yang mudah untuk dimengerti. Sejalan dengan hal tersebut Mellita \& Elpanso (2020) bahwa model lewin ini berupa tahapan-tahapan yang lelah direncanakan dalam menanggapi sebuah perubahan dan perbaikan yang berlangsung secara berkelanjutan yang dapat membantu sebuah perubahan dan perbaikan yang berlangsung secara berkelanjutan yang dapat membantu keberlangsungan suatu organisasi.

Sejalan dengan manajemen perubahan tersebut pelaksanaan pendidikan pada masa pandemi hendaknya dipahami secara menyeluruh bagi warga masyarakat pendidikan, terutama dalam sistem perubahan pembelajaran yang menimbulkan resiliensi pendidikan perlu keterlibatan masyarakat sebagai masyarakat pembelajar. Tokoh penting peletak dasar fundamental pendidikan Indonesia dalam manajemen perubahan Humanistik adalah Ki Hajar Dewantoro denga konsep Prinsip "Tringa" yaitu (Ngarti, Ngrasa, Nglakoni) artinya mengerti /memahami bahwa segala sesuatu membutuhkan pengertian, Merasa yang memberikan kesadaran dan keikhlasan untuk melaksanakan tugas tanggung jawab bersama dalam penyelengaraan pendidikan tentang kondisi perubahan pendidikan yang disebabkan Pandemi Covid-19 yang sedang melanda dunia, sehingga tidak ada lagi yang merasa terbebani dalam tanggung jawab terhadap keberlangsungan pendidikan.

\section{METODE PENELITIAN}

Dalam Best practice ini disusun dengan metode Systematik Literature Review (SLR) yaitu dengan mengumpulkan bahan-bahan kajian terlebih dahulu terkait kendala dalam pengambilan keputusan dan terkait dalam pengambilan keputusan itu sendiri baik berupa artikel, buku dan sumber lainnya. Setelah bahan kajian dikumpulkan selanjutrnya bahan tersebut diteliti dan dipelajari, kemudian penulis berusaha menyimpulkan sebuah pengetahuan baru berdasarkan hasil analisis terhadap bahan kajian tersebut. Dalam implikasi kepengawasan selanjutnya dikembangkan menjadi penelitian kualitatif dengan pendekatan deskriftif, tentang pengaruh 
positip pandemi Covid-19 terhadap resiliensi pendidikan, pendekatan stratetegis adaptif penyesuaian pembelajaran pendidikan di madrasah dengan mengacu pada manajemen perubahan model Kurt Lewin dengan pendekata humanis konsep pemikiran Tokoh pendidikan Nasional Ki Hajar Dewantoro dengan Prinsip Tringa ( Ngarti, Ngrasa, Nglakoni) dapat diterapkan dalam dunia pendidikan di Madrasah.

\section{HASIL DAN PEMBAHASAN \\ A. Fenomena Global Pendidikan dimasa Pandemi \\ a. Belajar di Rumah}

Pada awal mula penyebaran masiv Covid-19, semua satuan pendidikan menerapkan program Belajar Dari Rumah (BDR). Namun, setelah ditetapkan masa new normal, Kemendikbud mengambil sikap dengan mengeluarkan Keputusan Menteri No.719/P/2020 tentang Pedoman Pelaksanaan Kurikulum pada Satuan Pendidikan dalam Kondisi Khusus. Dalam keputusan menteri tersebut, tiap sekolah/satuan pendidikan diberikan kewenangan untuk melaksanakan kurikulum darurat sesuai dengan kondisi warga belajar dan wilayahnya. Untuk seatuan pendidikan yang berada di zona penyebaran pandemi berwarna kuning dan hijau, diperkenankan untuk melaksanakan pembelajaran tatap muka dengan protokol kesehatan yang ketat dan mengurus izin dituangkan dalam Surat Edaran Kemendikbud Nomor 4 Tahun 2020. Berdasarkan Surat Edaran Kemendikbud Nomor 4 Tahun 2020 tentang Pelaksanaan Kebijakan Pendidikan dalam Masa Darurat Penyebaran Corona Virus Disease (Covid-19), proses Belajar Dari Rumah (BDR) dilaksanakan dengan memperhatikan ketentuan berikut: (1) BDR memalui pembelajaran daring dilaksanakan untuk memberikan pengalaman belajar yang bermakna bagi siswa, tanpa terbebani tuntutan menuntaskan seluruh capaian kurikulum untuk kenaikan kelas maupun kelulusan; (2) BDR dapat difokuskan pada pendidikan kecakapan hidup antara lain mengenal pandemi Covid-19; (3) Aktivitas dan tugas pembelajaran BDR dapat bervariasi antar siswa, sesuai minat dan kondisi masing-masing, termasuk mempertimbangkan kesenjangan akses/fasilitas belajar di rumahl (4) Bukti atau produk aktivitas BDR diberi umpan balik yangbersifat kualitatif dan berguna dari guru, tanpa haruskan memberi skor/nilai kuantitatif.

Ketentuan yang tertera dalam surat edaran tersebut menjadi acuan pelaksanaan BDR di tiap satuan pendidikan di Indonesia. Keberhasilan pelaksanaan BDR bagi siswa merupakan tanggung jawab bersama antara guru dan orang tua. Plt Dirjen PAUD dan Dikmas, Harris Iskandar menyampaikan bahwa proses pembelajaran dari rumah harus melibatkan guru dan orang tua. Diharapkan dapat terwujud pendidikan yang bermakna dan tidak hanya berfokus pada capaian akademik saja. Senada dengan pendapat tersebut, Direktur Guru dan Tenaga Kependidikan Pendidikan Menengah dan Pendidikan Khusus, Praptono, menghimbau agar pelaksanaan belajar dari rumah tidak hanya berfokus pada aspek akademik, tapi ada penekananan pada life skill, karakter, dan sebagainya (sahabat keluarga. kemdikbud.go.id).

Pelaksanaan kegiatan belajar tatap muka terlebih dahulu. Sedangkan satuan pendidikan yang berada di zona merah dan oranye masih harus menerapkan program BDR secara penuh. Program BDR dicetuskan oleh Mendikbud, Nadiem Makarim sebagai solusi agar kegiatan belajar mengajar tetap dapat dilaksanakan selama masa pandemi Covid-19.Pada awal penetapan Indonesia Darurat Covid, Presiden Joko Widodo menyampaikan agar masyarakat dapat beraktivitas dari rumah, yang melliputi kerja dari rumah, sekolah dari rumah, dan beribadah dari rumah. Program ini menjadi dasar pelaksanaan BDR. Belajar Dari Rumah pada masa pandemi Covid-19 ini dimulai pada bulan Maret 2020 lalu. Peraturan tentang BDR

Sedangkan kebijakan Kementerian Agama mengeluarkan regulasi BDR diatur pada SK Dirjen Pendis Nomor 2791 Tahun 2020 tentang Kurikulum Darurat pada Madrasah dengan ketentuan sebagai berikut :

1. Aktivitas dan tugas pembelajaran pada masa Belajar dari Rumah dapat bervariasi antarsiswa, sesuai minat dan kondisi masing masing, termasuk mempertimbangkan kesenjangan akses/ketersediaan fasilitas belajar di rumah. Pemberian tugas pembelajaran wajib mempertimbangkan konsep belajar dari rumah, yaitu sebagai usaha memutus mata rantai 
penyebaran Covid-19, oleh karena itu beban tugas yang diberikan dalam kegiatan belajar dari rumah agar dipastikan tidak berlebihan dan dapat diselesaikan oleh siswa tanpa keluar rumah dan tetap terjaga kesehatan, serta cukupnya waktu istirahat untuk menunjang daya imunitas siswa;

2. Belajar dari rumah melalui pembelajaran daring/jarak jauh dilaksanakan untuk memberikan pengalaman belajar yang bermakna bagi siswa, tanpa terbebani tuntutan menuntaskan seluruh capaian kurikulum untuk kenaikan kelas maupun kelulusan. Madrasah dapat menyelenggarakan belajar dari rumah dengan memanfaatkan aplikasi e-learning madrasah melalui https://elearning.kemenag. go.id/web dan/atau aplikasi daring lainnya;

3. Belajar dari rumah lebih menitik beratkan pada pendidikan kecakapan hidup, misalnya pemahaman mengatasi pandemi Covid-19, penguatan nilai karakter atau akhlak, serta keterampilan beribadah siswa di tengah keluarga;

4. Bukti atau produk aktivitas belajar dari rumah diberi umpan balik yang bersifat kualitatif dan berguna dari guru, tanpa diharuskan memberi skor/nilai kuantitatif.

5. Khusus pada siswa RA pembelajaran dari rumah dilaksanakan dalam bentuk bermain di rumah bersama keluarga dan/atau orang tua.

\section{b. Penyederhanaan konten}

Tiap satuan pendidikan diberikan wewenang untuk mengatur kurikulum kondisi khusus sesuai dengan kebutuhan warga belajar. Pada kondisi khusus ini, satuan pendidikan diberikan kewenangan untuk memilih diantara: (1) tetap mengacu pada kurikulum nasional yang selama ini telah dilaksanakan; (2) mengau pada kurikulum nasional dengan KI dan KD yang telah disederhanakan untuk kondisi khusus yang ditetapkan oleh Kepala Badan Penelitian dan Pengembangan Perbukuan; atau (3) melakukan penyederhanaan kurikulum secara mandiri. Langkah ini dilakukan oleh Kemendikbud agar tiap satuan pendidikan tetapdapat memberikan pendidikan terbaik bagi siswa-siswinya di tengah pandemi global yang belum mereda.

\section{c. Fleksibilitas waktu}

Sedangkan dalam PTM Terbatas pembagian rombongan belajar dilakukan maksimal $50 \%$ kapasitas per kelas, sehingga 1 rombel terdapat 2 kali pertemuan dalam satu minggu. Dengan ketentuan 1-16 masuk hari senin dan rabu, nomor absen 17-32 masuk hari selasa dan kamis. Satu kali pertemuan PTM berlangsung selama 3 jam (pukul 07.00-10.0 WIB) . Setiap kelompok belajar melakukan 2 kali pertemuan dalam 1 minggu dengan jam masuk selang seling ( jeda beberapa menit ) tiap kelas agar anak tidak terjadi penumpukan saat pulang. Dalam PJJ dilakukan secara daring melaui Whastapp Group (WG) untuk memberikan materi kepada kelompok belajar yang pada hari itu tidak mendapat giliran masuk ke sekolah memberikan dan mengambil tugas pembahasan tugas yang dilakukan melalui PTM terbatas bagi yang giliran masuk dan lewat Zoom bagi yang giliran PJJ. Hari Ju'mat dipakai untuk melakukan evaluasi PTM terbatas di tiap minggunya (Panduan Pendidikan madrasah memasuki Normal baru, Direktorat KSKK.2021)

\section{B. Pemecahan Masalah}

Pandemi Covid-19 memberikan dampak yang begitu sangat besar bagi semua bidang kehidupan manusia, termasuk dalam bidang pendidikan. Dampak yang ditimbulkan bisa dilihat dalam sisi positif dan sisi negatif. Pada umumnya orang melihat pandemi covid-19 sebagai sebuah ancaman, wabah yang merugikan bagi manusia pada umumnya yang menyebabkan kehidpan masyarakat meng-alami situasi-situasi yang tidak menyenangkan yang disebabkan Pandemi Covid-19. Apalagi pelayanan pendidikan membuat Keadaan-keadaan yang tidak menyenangkan serta tidak sesuai dengan harapan masyarakat seperti layanan pendidikan pada masa normal dahulu, hal inilah yang dapat menimbulkan tekanan tersendiri bagi dunia pendidikan sebagai resiliensi pendidikan. 
Resiliensi disebut sebagai kemampuan untuk "mempertahankan stabilitas psikologis dalam menghadapi stres" (Keye \& Pidgeon, 2013). Selanjutnya Fernanda Rojas (2015) menyatakan resiliensi sebagai kemampuan menghadapi tantangan, resi-liensi akan tampak ketika seseorang meng-hadapi pengalaman yang sulit dan tahu bagaimana menghadapi atau beradaptasi dengannya.

Resiliensi secara umum mengarah pada pola adaptasi positif selama atau sesudah menghadapi kesulitan atau resiko. Resiliensi adalah ide yang mengacu pada kapasitas sistem dinamis untuk bertahan atau pulih dari gangguan (Masten, 2007). Demikian pula dengan pendapat Grotberg (1995) yang menyatakan bahwa resiliensi adalah kapasitas universal yang mengizinkan seseorang, kelompok atau komunitas untuk mencegah, meminimalisasi atau mengatasi efek yang merusak dari kesulitan. Resiliensi merupakan kapasitas manusia untuk menghadapi dan mengatasi kesulitan serta diperkuat atau ditransformasikan oleh kesulitan-kesulitan dalam hidup.

Namun demikian, seringkali ditemu-kan resiliensi manusia dalam menghadapi berbagai kesulitan hidup kurang optimal. Manusia lebih memilih menyerah pada keadaan atau bahkan mengalami berbagai gangguan baik dalam kemampuan sosial, mental ataupun fisik. Mereka tidak mampu menjaga keseimbangan dalam menghadapi tekanan yang kuat. Meningkatkan resiliensi pendidikan adalah tugas yang penting karena hal ini dapat memberian pengalaman bagi penyelenggaraan pendidikan dalam menghadapi tantangan dan kesulitan pelaksanaan pendidikan. Dengan meningkatkan resiliensi pendidikan pelaku pendidikan mau tidak mau dituntut dapat mengembangkan ketrampilan seperti bagaimana berkomunikasi, kemampuan yang realistik dalam membuat rencana pelaksanaan pendidikan dan mampu mengambil langkah yang tepat bagi penyelengaraan pendidikan tetap berjalan seiring perubahan pola pembelajaran , sebagaiman pendapat Fernanda Rojas (2015) menyatakan resiliensi sebagai kemampuan menghadapi tantangan, resi-liensi akan tampak ketika seseorang meng-hadapi pengalaman yang sulit dan tahu bagaimana menghadapi atau beradaptasi dengannya.

Dalam bingkai optimisme adaptasi di era pandemi dipahami dengan bahwa hadirnya virus covid-19 menjadi sebuah peluang atau pendorong bagi dunia pendidikan untuk maju, bergerak, berinovasi menuju eksistensi pendidikan tetap berjalan. Dengan kata lain, situasi pandemi cavid-19 saat ini menjadi "hijrahnya dunia pendidikan ke era digital" bagi semua guru di Indonesia untuk maju dan bangkit untuk menuju peningkatan mutu pendidikan, pembelajaran, dan kualitas profesional sebagai pendidik. Adanya Pandemi memaksa semua pendidik juga berfikir ulang pendekatan dalam pembelajaran yang dapat mendukung percepatan terwujudnya pembelajaran terhadap teknologi dan mendorong percepatan pembangunan platform pendidikan nasional berbasis teknologi dengan manajemen perubahan pendidikan.

Pendekatan model yang dapat mengadaptasi perubahan pendidikan, salah satunya adalah model manajemen perubahan Kurt Lewin. Teori model Lewin merupakan model perubahan fundamental awal yang terencana dengan menjelaskan kekuatan dari perjuangan untuk mempertahankan status quo dan mendorong untuk perubahan ( Lewin dalam Hussain.et al, 2016). Analogi teori Lewin dalam manajemen perubahan sebagai proses es balok untuk dibentuk sesuai sesuai yang diinginkan maka perlu dicairkan terlebih dahulu (Unfreeze), kemudian dimasukkan kedalam cetakan sesuai bentuk yang diinginkan ( Change) dan dibekukan kembali menjadi balok yang berbeda (Oktaviana Nurhaeni,2020)

Ada tiga tahap penting menurut Teori Lewin yaitu tahap pertama Mencairkan (Unfreeze). Dimana pendidikan pada saat pandemi Covid-19 tidak memungkinkan pembelajaran tatap muka dalam rangka mecegah meluasnya wabah Covid-19. Dengan demikian perlu pengertian dimasyarakat adanya perubahan yang dibutuhkan untuk merubah status quo yang selama ini pembelajaran dibatasi oleh ruang dan waktu dalam ruang kelas secara fisik berubah menjadi ruang kelas yang berbentuk maya dengan dengan sistem pembelajaran Jarak Jauh (PJJ) dengan menggunakan pendekatan ( Daring, Luring, Blended Leraning). 
Sejalan dengan teori Lewin ini Salah satu konsep pemikiran besar yang menjadi dasar pemikiran telah diberikan oleh tokoh bapak pendidikan nasional Indonesia, Ki Hajar Dewantoro dengan Prinsip Tringa (Ngarti,Ngrasa,Nglakoni) yaitu Ngarti artinya mengerti/mengetahui bahwa segala sesuatu membutuhkan pengertian, kesadaran serta kesungguhan, hal ini berkaitan dengan pengertian masyarakat dalam memahami secara untuh tentang kebijakan pemerintah dalam menangani wabah Covid-19 terhadap kebijakan pendidikan. Oleh karena guru juga wajib Mengerti dalam pengertian ini adalah mengerti akan makna secara kontekstual apa yang dimaksud dengan Kurikulum Pendidikan di masa Darurat Covid-19. Ketika sudah mengerti dan memahami arti sebenarnya tentang Pelaksanaan Kebijakan Pendidikan dalam Masa Darurat Penyebaran virus Disease (Covid-19), maka siapaun akan tergerak untuk mengambil peranan dalam penyelenggaraan pendidikan.

Kemudian pada tahap kedua Teori Lewin adalah Perubahan (Change). Pada tahap ini merupakan tahap yang penting untuk memulai arah perubahan yang ada dalam menuju tujuan yang diinginkan. Sebagaimana pada tahap ini dalam prinsip Tinga adalah Ngrasa artinya merasakan bahwa pelaksanaan Kurikulum Pendidikan di masa Darurat Covid-19 merupakan kepentingan bersama berbagai pihak seluruh komponen pendidikan. Ketika sesorang sudah mengerti dan memahami tetapi belum merasakan belumlah lengkap, dengan merasakan akan ada upaya usaha memperjuangkan secara terus menerus terhadap pelaksanakan penyelenggaraan pendidikan Kurikulum Pendidikan di masa Darurat Covid-19 dapat berjalan secara optimal.

Tahap ketiga adalah Membekukan Kembali (Unfreeze), pada tahap ini perubahan telah terbentuk dan cara baru telah diimplementasikan dan perlu dipertahankan untuk dapat berlangsung secara lama dengan ciri-ciri adanya kestabilan dalam pelaksanaan dengan deskripsi kerja yang tetap sebagai cara baru yang dirasakan dalam perubahan telah nyaman digunakan. Seiring sejalan dengan tahap ketiga ini dalam Prinsip Tringa adalah Nglakoni artinya Menjalankan dengan sebaik-baiknya, seteleh mengerti dan merasakan maka perlu melaksanakan dengan sebaik-baiknya dengan kesadaran mengerjakan dan menjalankan tugas dan tanggungjawab pendidikan. Adapun alur pemikiran konsep best practice ini sebagaimana dalam alur pemecahan masalah.

\section{E. Alur Berfikir dan Pemecahan Masalah}

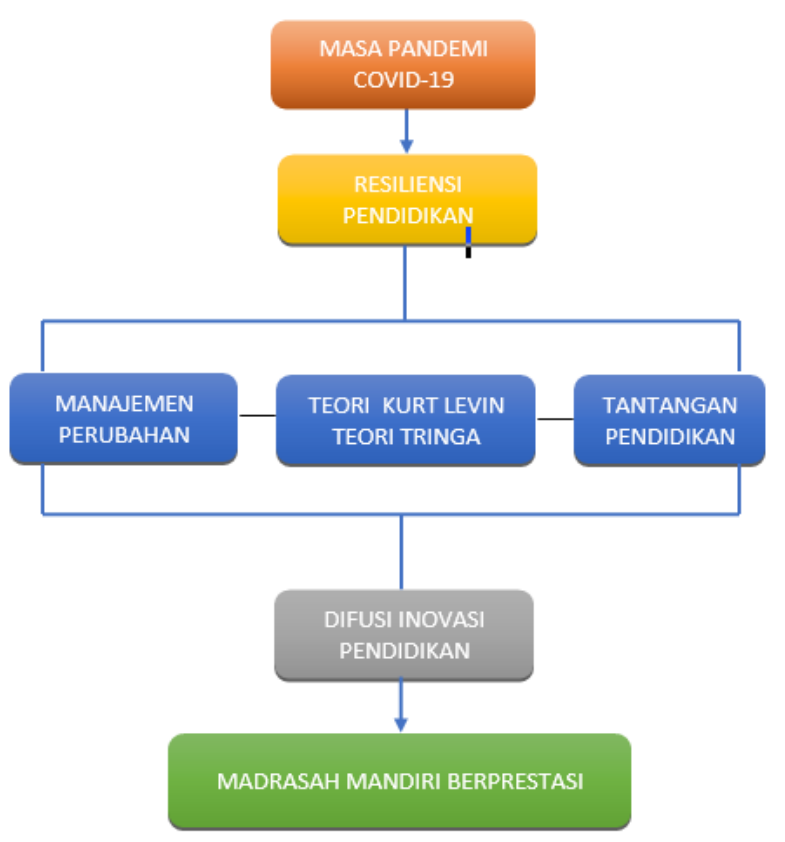

Gambar 1. Skema Alur Berfikir 


\section{F. Pemecahan Masalah Era New Normal}

a. Review Kurikulum

Dalam review kurikulum berkaitan dengan aspek : 1)Tujuan ; review Kompe -tensi dan Pengembanga dalam Pembelajaran; 2) Isi : Pembelajaran HOTS di sesuaikan dengan jenjang, tema tentang wabah, kedalaman materi serta dibandingkan dengan keluasan ; 3) Kegiatan Evalausi menggunakan Model Blended learning.

b. Metode/Media/sumber

a) Metode Pembelajaran daring dengan melibatkan komunikasi dengan orang tua;

b) Media Pembelajaran dengan pemilihan teknologi daring, pemanfaatan teknologi daring, pembuatan teknologi daring.

c. Sumber Pemebelajaran dengan menyeleksi sumber belajar daring, pembuatan sumber belajar daring serta modul pembelajaran daring.

d. Kompetensi Pendidik terhadap penguasaan Kurikulum

(1) Kemampuan mereview kurikulum,

(2) kemampuan pengembangan perangkat pembelajaran baru,

(3) tidak membebani siswa berlebihan.

e. Kapasitas Madrasah berkaitan dengan hal

(a) Fasilitas : Daya tampung, Tek -nologi Informasi, Media ;

(b). Aturan : Review tata tertib, Protokol keseha- tan, Panduan orang tua;

(c) Budaya : Hidup Bersih dan sehat (Zuhri,M. 202)

\section{G. TINDAK LANJUT}

1. Implementasi Supervisi Pendidikan

Kepala sekolah tidak lagi merupakan guru yang diberi tambahan, tetapi guru yang ditugasi mengelola madrasah (Permendikbud No. 6 tahun 2018). Dengan demikian kepala sekolah diharpakan lebih fokus untuk memastikan bahwa semua kegiatan sekolah mengacu pada Standar Nasional Pendidikan dengan mengerahkan semua potendi sumber daya di sekolah untuk mencapai SNP. Sebagai salah satu beban tugas kepala sekolah adalah melaksanakan supervisi kepada guru dan tenaga kependidikan (Permendikbud No. 15 tahun 2018 Tentang Pemenuhan tugas Guru, Kepala Sekolah dan Pengawas Sekolah) adalah melakukan supervisi akademik yang erat kaitannya dengan penilaian kinerja guru dalam pembelajaran untuk meningkatkan kompetensi guru dalam pembelajaran.

Dalam kegiatan supervisi akademik kepala sekolah selaku suprvisor memusatkan perhatian pada perangkat pembelajaran yang maupun skenario pembelajaran yang akan diterapkan. Pada tahap berikutnya kegiatan Inti kepala sekolah selaku supervisor mengamati penugasan kelas baik secara klasikal, kelompok atapun tugas individu.Kepala sekolah juga harus mengamati media pembelajaran dan alat yang dipakai berkaitan dengan relavansi materi pembelajaran, apakah mampu mendukung penjelasan guru serta mampu mempermudah siswa memahami materi atau tidak. Selanjutnya berkaitan dengan penilaian belajar yang perlu diamati apakah sesuai atau tidak penilaian belajar yang diberikan guru dengan jenis tagihan yang seharusnya dengan kesesuaian indikator dan kompetensi yang diharapakan. Sesi terakhir yang perlu dicermati kepala adalah kegiatan penutup yang meliputi bagaiaman guru mengajak siswa menyimpulkan materi pembelajaran,memberi penguatan serta pemberian tugas dan lainnya.

Masa tanggap darurat pandemi Covid-19 belumlah jelas kapan berakhir,mau tidak mau kepala sekolah harus mengubah strategi supervisi yang dilakukan dengan gurunya terkait dengan teknis strategi supervisi akademik. Hal ini dilakukan karena pembelajaran tidak lagi dilakukan secara tatap muka di kelas, melainkan secara daring (dalam jaringan), luring (luar jaringan) ataupun perpaduan keduanya (blended). Oleh sebab itu pengambilan langkah-langkah yang tepat dan koordinasi yang baik dengan seluruh pihak perlu ditlakukan di tengah wabah Covid-19 menuju proses pembelajaran berjalan lancar dalam keberlangsungan pendidikan.

Dengan adanya keputusan yang mensyaratkan siswa melakukan pembelajaran dari rumah maka kepala sekolah harus mampu menerapkan manajemen perubahan dalam 
pengelolaan sekolah kepada guru,siswa, dan orang tua secara cepat dan akurat. Dengan adanya kegiatan supervisi akademik diharapakan manajemen perubahan dalam pengelolaan pembelajaran guru . Kegiatan supervisi akademik di sekolah merupakan upaya pembinaan yang dilakukan kepala sekolah terhadap kegiatyan guru dalam upaya meningkatkan kinerja guru dalam proses pembelajaran serta untuk menciptakan proses pembelajaran yang efektif ( Mulyasa,2011)

Supervisi dimasa pandemi covid 19 dilakukan denga pendekatan supervisi klinis. Supervisi klinis adalah mengembangkan kemampuan guru agar bertanggung jawab terhadap kinerja guru dan terbuka adanya manajemen perubahan. Supervisi klinis dilakukan dengan tatap muka yang memungkinkan kepala sekolah gur bersama-sama menganalisis masalah pemeblajaran jarak jauh yang dilakukan di rumah (PJJ). Pelaksanaan supervisi klinis dilakukan dengan mempersiapkan dokumen untuk menentukan skala prioritas dan menyiapkan instrumen pengamatan maupun kriteria penilian yang akan dilaksanakan. Salah satu bentuk kegiatan yang mudah dilaksanakan dalam kegiatan pelaksanan supervisi klinis ini adalah dengan Zoom atau Google Meet selama 2x30

Pengamatan dilaksanakan dengan menggunakan instrumen, strategi dan kriteria yang telah disepakati,. Fokus pengamata mulai kegiatan pendahuluan, kegiatan inti dan kegiatan penutup dan setelah selesai ditindaklanjuti dengan refleksi dan klarifikasi. Hasil analisis kemudian dikoordinasikan dengan guru untuk mendapatkan tanggapan. Tahap ini disebut tahap tindak lanjut berupa refleksi dan klarifikasi. Apabila ada keberatan dari guru yang disupervisi maka klarifikasi dan refleksi ditunda pada kesempatan lain. Dengan adanya Supervisi klinis kepala sekolah maka diharapkan progam supervisi klinis kepala sekolah dapat berjalan dengan baik. Hasildari evaluasi supervisi klinis diyakini sebagai solusi pemecahan masalah pembelajaran yang diyakini mampu meningkatkan kinerja guru di masa pandemi Covid-19 cukup efektif dalam membangun semangat guru dalam mempersiapakan proses pembalajaran yang bermutu dan bermakna untuk menjaga kualitas peningkatan mutu pembelajaran agar tidak stagnan dengan adanya pandemi Covid-19

\section{Urgensi Madrasah Promosi Kesehatan Pasca Pandemi}

Upaya promosi kesehatan dalam sebuah negara menjadi salah satu ukuran tentang sejauh mana investasi negara dalam pendidikan memberikan manfaat cukup besar dalam memahamkan arti penting kesehatan ( World Health Organisation,2000) . Promosi Kesehatan berguna untuk memastikan investasi tidak terbata hanya pada pencapaian kebutuhan akan kesehatan, namun juga sebgai alat untuk mengawasi seseorang untuk memahami berbagai faktor yang mempengaruhi kesehatan(Nutland,will, cragg, 2015)

Fokus global terhadap isu kesehatan di lingkungan pendidikan sudah jauh hari direspon melalui The Global School Health Initiative and Information Series dengan Progam Health Promoting School Sekolah Promosi Kesehatan. Progam ini diarahkan untuk dapat mengintensifkan upaya memperkuat kapasitas sekolah sebagai media mempromosikan kesehatan dalam aktivita hidup dan belajar siswa.

Konsep kesehatan tidak hanya cukup ditanamkan melalui pembiasan hidup bersih, namun perlu menjadi bagian integratif dengan kurikulum sekolah tidak hanya menekankan penyampaian informasi kesehatan fungsioanl ( pengetahuan dasar dan esensial). Kurikulum juga harus mampu membentuk nilai kepercayaan dan kepercayaan pribadi yang mendukung perilaku sehat yang mengimbas pada norma kelompok yang menghargai gaya hidup sehat ( Center for Disease Control and preventation, 2014). Jika seudah begitu siswa terbiasa mengadopsi, berlatih dan mempertahankan perilaku peningkatan yang meningkatkan kesehatan mereka dan lingkungan sekitar. Perilaku Kesehatan yang baik akan mendukung proses keberhasilan pendidikan begitu juga sebaliknya.

Pemberlakuan SKB 4 Menteri tentang Panduan Penyelenggaraan Pembelajaran di Masa Pandemi (COVID-19) tanggal 30 Maret 2021, menyatakan tiap sekolah wajib memberikan layanan belajar tatap muka terbatas setelah seluruh pendidik dan tenaga kependidikan 
menerima vaksin Covid-19, Pelaksanaan PTM terbatas di sekolah/madrasah ini masih menjadi pembicaraan di masyarakat. Masyarakat masih mempertanyakan tentang efektifitas penerapan protokol kesehatan di sekolah/madrasah, mengingat sifat anak-anak yang belum sepenuhnya memahami betapa pentingnya prokes sebagai perlindungan dari wabah. Hal inlah yang menjadikan orang tua merasa khawatir pelaksanaan PTM terbatas akan munculnya kembali penyebaran covid-19 pada anak-anak mereka.

PTM terbatas juga memiliki tantangan resiko yang sangat besar juga seperti isu kesehatan saat ini. Banyak kajian mengungkap bahwa terdapat hubungan erat antara kesehatan dan pendidikan. Kesehatan yang baik mendukung keberhasilan pembelajaran, begitupun sebaliknya. Upaya promosi kesehatan sebuah negara menjadi salah satu tolak ukur tentang sejauh mana investasi pemerintah dalam pendidikan memberikan manfaat yang cukup besar dalam memahamkan arti penting kesehatan (World Health Organisation.2000).

Sebagai institusi, sekolah/madrasah memegang peranan penting dalam mengimplementasikan nilai-nila kesehatan anak melalui aktivititas guru dalam aktivitas belajar mengajar tentang Konsep mengenai kesehatan tidak cukup hanya ditanamkan melalui pembiasaan sikap hidup bersih, namun perlu menjadi bagian integratif dengan kurikulum sekolah. Kurikulum kesehatan sekolah tidak sekadar menekankan penyampaian informasi kesehatan fungsional (pengetahuan dasar dan esensial). Kurikulum juga harus mampu membentuk nilai dan kepercayaan pribadi yang mendukung perilaku sehat, dan mengimbas pada norma kelompok yang menghargai gaya hidup sehat.

Lantas bagaimana kesiapan sekolah/madrasah dalam menyikapi pelaksanaan PTM terbatas harus sesuai kebijakan PTM sekolah/madrasah harus mengacu pada SKB 4 Menteri tentang Panduan Penyelenggaraan Pembelajaran di Masa Pandemi (Covid-19), serta menyediakan lingkungan sekolah yang mendukung pelayanan kesehatan siswa dan warga sekolah. Disisi lain Manajemen sekolah harus memaksimalkan unit khusus yang melayani kesehatan sekolah (UKS) dengan baik, tidak sekadar menjalankan peran pencegahan, namun juga promotifnya tentang pentingnya menjaga kesehatan dengan slogan-slogan pentingnya kesehatan bagi siswa. Sekolah juga perlu berfokus pada pencapaian pendidikan kecakapan hidup mengenai kesehatan, untuk memberikan pengalaman belajar yang lebih bermakna bagi siswa tentang kesehatanya.

Dalam pembelajaran tatap muka terbatas di satuan pendidikan dilaksanakan melaui (dua) fase sebagai berikut: a. Masa Transisi Berlangsung selama 2 (dua) bulansejak dimulainya pembelajarantatap muka terbatas di satuan pendidikan; b. Masa Kebiasan Baru setelah masa transisi selesai maka pembelajaran tatap muka terbatas memasuki kebiasan baru.

Pelaksanaan PTM terbatas sekolah/madrasah, beberapa hal yang perlu diperhatikan oleh sekolah/madrasah : pertama, keterlibatan peran aktif semua pemangku kepentingan dalam pendidikan dalam penerapan prokes, seperti guru, siswa, orang tua, dan masyarakat, secara aktif terlibat dalam mempromosikan pentingya kesehatan di lingkungan sekolah. Kedua, komitmen sekolah menyediakan lingkungan sekolah sehat dan aman termasuk fasilitas pembelajaran, sanitasi fisik, iklim kepedulian, kebebasan dari pelecehan dan kekerasan, perawatan, kepercayaan, suasana saling menghormati dan upaya promosi kesehatan. Ketiga, menyediakan muatan kurikulum pendidikan kesehatan berbasis keterampilan, yang bisa meningkatkan pemahaman siswa tentang kesehatan dalam perilaku sehari-hari serta membangun pembiasaan terhadap upaya pencegahan penyakit berbasis kepedulian antar sesama siswa. Keempat, Memberikan kemudahan akses layanan kesehatan kesehetan baik internal (skrining kesehatan, diagnosis, pemantauan pertumbuhan dan perkembangan, vaksinasi, dan lain sebagainya) maupun ekternal sekolah dengan kemitraan (lembaga kesehatan/dinas kesehatan) setempat.

\section{KESIMPULAN}

Dalam rangka untuk mengatasi krisis yang terjadi akibat perubahan sebagai dampak pandemi covid-19 di bidang pendidikan menuntut adanya penyesuaian dan adaptasi terhadap 
perubahan untuk keberlangsungan pendidikan tetap terlaksana dengan baik . Hal inilah dunia pendidikan dihadapkan manajemen perubahan tatakelola proses pembelajaran. Salah satu model yang manajemen perubahan adalaha model Kurt Lewin dengan pendekatan humanistik dengan prinsip "Tringa" Ki Hajar Dewantoro. Dampak dari manajemen perubahan membawa perubahan pula dal;am pola penjaminan mutu pendidikan. Selain Regulasi pemerintah , dalam penjaminan mutu keberlangsungan pelksanaan pendidikan adalah elemen supervisi pendidikan dalam hal ini adalah Pengawas Madrasah, Kepala Madrasah berkaiatan dengan manajemen perubahan. Kebiajakan pemerintah dalam menagani pandemi covid-19 dalam dunia pendidikan telah terbit beberapa aturan dalam rangka pencegahan wabah Covid-19. Regulasi pemerintah akan dapat terlaksana dengan baik perlu adanya difusi inovasi pendidikan sampai pada tahapan yang pelaksana pendidikan di lingkup lembaga pendidikan dan masyarakat pengguna pendidikan.

Pengawas madrasah dalam perannya sebagai supervisor akademik dan manajerial menuntut adanya pola strategi baru dalam melaksanakan kontrol pelaksanaan kebijakan pendidikan. Sarasaran utama adalah pembinaan kepala madrasah, guru dan tenaga kependidikan. Tidak kalah pentingnya Kepala Madrasah sebagai pengelola lembaga pendidikan hendaknya mampu dengan cepat beradaptasi dengan manajemn perbuhan berdasarkan regulasi pemerintah dalam pendidikan. Dengan demikian difusi inovasi pendidikan dapat terlaksana baik pada tataran guru dalam memahami kurikulum, proses poembelajaran, media pembelajara, metode pembelajaran,sumber pembelajara, waktu pembelajaran,serta pelibatan orang tua sebagai pembelajar dengan tuntutan perbuhan pendidkan ke era digitalisasi.

\section{DAFTAR PUSTAKA}

Dewantara, K. H. (1989). Dasar-dasar Konsepsi Ki Hajar Dewantara,Majlis Luhur Persatuan Taman Siswa.Yogyakarta.

Dewantara, K. H. (2004). Pendidikan,Bagian Pertama.Majlis Luhur Persatuan Taman Siswa. Cetakan ke 3.Yogyakarta

Dirjen Pendis, Nomor 2791. (2020) Tentang Kurikulum Darurat pada Madrasah, Kemenag : Jakarta

Fernando, R. L. (2015). Factors affecting academic resilience in middle school students: A case study. Gist Education and Learning research Journal, 11(11),63-78.

Grotberg, E. H. (1995). A Guide to promoting resliency in chhildren: Strengthening the human spirit. Early Childhood Development : Practice And Reflections, 8.

Hussain, S, T., et al. (2016). Kurt Lewin's Cahnge Model: A Critical review of the role leadership and employee involvement in organization change. Journal of innovation 7 knowledge, 3(2) : 123-127

Kepetusan Menteri Pendidikan, No.719/P/2020. Tentang Pedoman Pelaksanaan Kurikulum Pada Satuan Pendidikan Dalam kondisi Khusus. Kemendikbud: Jakarta

Keye, M. D. \& Pidgeon, A.M. (2013). An Investigationof the relationship between resilience, mindfulness, and academic self-Efficacy. Open Journal Of Social Sciences, 1(6),1-4.

Masten, A. S. (2007). Resiliencce in developing systems:Progess and Promise as the Fourth waves rises. Development and Psychopatology.19.921-930

Mellita, D., Elpanso, E. (2020). Model Lewin Dalam Manajemen Perubahan: Teori Klasik Menghadapi Disrupsi Dalam Lingkungan Bisnis. Jurnal MBIA,19(2),142-152.

Mulyasa. (2011). Kurikulum Berbasis kompetensi Konsep, Karakteristik dan Implementasi. Bandung: PT. Remaja Rosdakarya.

Nutland, Will, Lisa Cragg. (2015). Health Promotion Practice. Amazon.co.uk: Books

Oktaviana, L. \& Nurhaeni, I. D. A. (2020). Management of the Educational Change the Covid 19 Pandemic Era. Advances in Sosial Science, Education and Humanities Researsch, vol. 510.

Permendikbud, No. 6. (2018). Peraturan Menteri Pendidikan tentang Penugasan Guru Sebagai Kepala Sekolah. Kemendikbud: Jakarta 
Vol 1. No. 4, Oktober 2021 P-ISSN : 2774-8030, e-ISSN : 2774-8030

Rahim, M. R.(2020. Pandemi Covid-19 Peluang Unjuk Diri Guru Milenial. https://mediaindonesia.com/read/detail/309388-pandemik-covid-19-peluang-unjuk-diriguru-milenial

SE.Kemendikbud, No.4. (2020). Tentang Pelaksanaan Kebijakan Pendidikan dalam Masa Darurat Penyebaran Corona Virus Disease (Covid-19), Kemendikbud.Jakarta

SKB 4 Menteri. (2021). Tentang panduan Penyelenggaraan Pembelajaran di Masa Pandemi Corona Virus Disease (Covid-19). Jakarta:31 Maret 2021.

Umar.A.(2021). Pendidikan Madrasah Memasuki Normal Baru. Dirjen Pendis: Kemenag.

Webb,W.B.(1985). A Further analysis of age and sleep deprivation effects.Psychophysiology,22(2),156-161

Zuhdi, M. (2021). Menuju Normal Baru Madrasah Pasca Pandemi. UIN Syarif Hidayatullah: Jakarta. 